\title{
Position of Agriculture in Sub-Saharan GDP Structure and Economic Performance
}

\author{
K. Tomšík ${ }^{1}$, L. Smutka ${ }^{1}$, J.-P. E. Lubanda ${ }^{1}$, H. Rohn² \\ ${ }^{1}$ Department of Economics, Faculty of Economics and Management, Czech University of Life Sciences \\ Prague, Czech Republic \\ ${ }^{2}$ ITMO University, Institute of Refrigerating and Biotechnology, St. Petersburg, Russia
}

\begin{abstract}
Anotace
Afrika je kontinent se specifickými problémy, které odlišují tuto část světa od jiných regionů. Nízká ekonomická výkonnost řadí většinu států mezi nejchudší země světa. Avšak africké zdroje a nevyužité př́ležitosti skýtají značný potenciál pro ekonomický rozvoj. Zemědělský sektor hraje v africkém ekonomickém rozvoji specifickou roli, jelikož jeho podíl na celkové zaměstnanosti a tvorbě HDP je vysoký. Cílem př́spěvku je analyzovat změny ve struktuře HDP (zemědělství, průmyslu a sektoru služeb), k nimž došlo ve vybraných afrických (subsaharských) zemích během uplynulého dvacetiletého období. Vývoj hodnoty HDP a HDP/obyvatele v sub-saharské Africe je komparován s vývojem světového HDP a HDP/obyvatele. Vlastní srovnání je realizováno prostřednictvím analýzy postavené na logaritmické regresy a výpočtu elasticity HDP a HDP/obyvatele ve vztahu k vývoji hodnoty HDP generovaného zemědělstvím, průmyslem a službami. Zvláštní pozornost je věnována postavení zemědělství ve vztahu k ostatním odvětvím. Výsledky indikují hlavní trendy v ekonomickém rozvoji a poukazují na specifikum, že zatímco řada subsaharských států dosáhla moderního typu ekonomiky s převahou služeb ve struktuře HDP, zemědělství dominuje ve většině zemí z hlediska zaměstnanosti. Proces transformace v subsaharské Africe stále nedosáhl úrovně globální ekonomické transformace. V budoucnu lze očekávat výrazné snížení podílu zemědělství na celkovém HDP a rostoucí roli zpracovatelského průmyslu a zejména služeb v HDP daného regionu.
\end{abstract}

\section{Klíčová slova}

Subsaharská Afrika, hospodářský rozvoj, zemědělství, průmysl, služby, hrubý domácí produkt.

\begin{abstract}
Africa is a continent with specific problems differentiating this part of the world from other regions. Low economic performance ranks most of African countries among the poorest. On the other hand, African resources and unexploited opportunities offer a potential for a considerable economic development. Agricultural sector plays a specific role in African economic development because its share in total employment and GDP formation is enormous high. The aim of the paper is to analyze main changes in area of GDP structure formation (agricultural, industrial and services sector) which have occurred in selected African (Sub-Saharan) countries during a twenty-year period. The GDP and GDP per capita in Sub-Saharan countries are compared with the world GDP and GDP per capita. The comparative analysis is performed through logarithmic regression and elasticity analysis. The idea is to analyse the relationship existing between GDP and GDP per cap in relation to the GDP value generated by agriculture, industry and services sectors. The special attention is devoted to the position of agricultural sector in relation to the other sectors. The results indicate main trends in economic development and point to the specifics that while many Sub-Saharan countries have reached the modern type of economy with prevailing services in GDP composition, agriculture still dominates in most countries in terms of employment. From the economic point of view it is worth noting that the transformation process in Sub-Saharan Africa still has not reached the level of the global economic transformation. A significant reduction of agriculture's share in total GDP is to be expected in the future, it is also possible to expect an increasing role of processing industry and especially of services in the regional GDP.
\end{abstract}

JEL classification: E 


\section{Key words}

Sub-Saharan Africa, economic development, agriculture, industry, services, gross domestic product.

\section{Introduction}

Africa is one of the most specific regions within the world economy. More than one billion people living in Africa represent over $15 \%$ of total world population Jenicek (2010). However, its share in global economy is about $2-3 \%$. African specifics are apparent mostly in the Sub-Saharan region. Population in this part of Africa reaches about 900 million which represents $12.7 \%$ of total world population but its share in global economy (in terms of GDP) is less than $1.7 \%$. Africa and especially its Sub-Saharan part has experienced a very specific and also very dynamic economic development over the recent two decades Thies (2007); Ahmed andSuardit (2007); Ndulu (2006).

The world economy changed significantly in the period after the end of the cold war. The removal of barriers between the western and eastern blocks affected not only the countries directly involved in the west-east competition, but a significant effect was experienced in the case of those countries which were formerly satellites of the antagonistic blocks or which were performing their policies on the edge between the two competing groups. In the early ' 90 s, African and especially the Sub-Saharan countries opened a new chapter of their economic development (Maitah et al., 2014). During the recent two decades $(1990$ - 2011), the countries transformed their economies, and the structure of their GDP formation changed significantly. African countries experienced a rapid growth in the service and industrial sectors and a decreasing proportion of agriculture and mining. Another important factor influencing economic development in Sub-Sahara has been a growth of foreign trade in individual countries Johnson (2005); Bussmann et al. (2005). The Sub-Saharan countries have become more involved in the world trade Anderson et al. (2004). During the last two decades, foreign trade became an important component of their GDP formation. Unfortunately, territorial and commodity structure of the foreign trade is still not developed enough Kirkpatrick and Watanabe (2005). This applies especially to the intra-regional trade Tekle et al. (2008). Despite many formal agreements, the mutual trade remains at a low level. Intraregional trade thus represents only about $10 \%$ of the total Sub-Saharan foreign trade. African countries are more dependent on trade with Europe and Asia than on trade within the region. Such situation is specific compared with other regions, e.g. Europe (about $70 \%$ of foreign trade operations are performed within Europe), Asia (50\%) and America (over 50\%).

Very strong position of the agricultural sector belongs to specific features of African economies. The agricultural population represents almost $60 \%$ of the total African population (675 million). Agricultural sector also provides working opportunities for more than $51 \%$ of the total economically active population (237 million). The share of the agricultural sector in total GDP formation is very high (in comparison to the rest of the World), the value exceeds $10 \%$ in average, but there are also countries where the share this share reaches $30-40 \%$.

The aim of the paper is to analyze main changes in area of GDP structure formation (agricultural, industrial and services sector) which have occurred in selected African (Sub-Saharan) countries during a twenty-year period.

\section{Materials and methods}

The paper is analysing the GDP formation and structure in selected Sub-Saharan countries in the period 1990 - 2011 (The mentioned time period is chosen because of limited data availability. Available data for 2012 and 2013 are not complete for all Sub-Saharan countries.). The GDP is expressed in USD, both in current and constant prices (2005). The changes are analysed both in relation to total value and on a per capita basis. The idea is to identify main development trends in the Sub-Saharan region and differences among individual Sub-Saharan countries with the aim to determine particular groups of African countries by their economic structure as well as to find differences in their GDP formation. For this reason, the paper divides the countries surveyed into four groups according to the structure of their GDP formation: agriculture, services, industry (ASI); industry, services, agriculture (ISA); services, industry, agriculture (SIA); and services, agriculture, industry (SAI).

The above mentioned typology of classifying countries by their economic structure is based 
on a method defined by A. Holub (1970). According to Holub (1970), three historical stages of economic development exist: the traditional stage (where agriculture is the main economic driving force), transitional (with main economic driving force of industry) and modern economy (the sector of services as the main economic driving force). This theory provides a basis for analysing structural development of the GDP formation in SubSaharan countries and for identifying differences among the analysed countries in relation to their GDP structure and formation.

Main data have been provided by the World Bank (WDI database). The analysis is focused especially on the Sub-Saharan region which consists of about fifty countries at different stages of their economic development. Because of limited data availability, 37 countries located in Sub-Sahara and North Africa have been selected.

GDP formation in the selected countries has been analysed from three different perspectives, namely the GDP in agricultural, industrial and service sectors. A special part of the paper is focused on the GDP analysis at the per capita level. The GDP per capita is analysed on the same methodological basis used for the GDP as a total. The analysis aims to highlight the existing differences between the total GDP and GDP per capita development trends, which makes it possible to understand real problems of economic development in Sub-Saharan Africa.

The Sub-Saharan countries' GDP and GDP per capita are analysed in relation to agricultural, industrial and services sectors. The mutual relationship between the total GDP and its particular components is analysed using methods of regression and elasticity analysis (Hindls et al, 2007). The analysis of elasticity is based on logarithmic regression. The values coming into the analyses are collected at constant 2005, USD prices.

$Y($ total GDP $)=\beta_{0}+\beta_{1} \ln X_{1}$ (Agricultural GDP $)$ $+\beta_{2} \ln X_{2}$ (Industrial GDP) $+\beta_{3} \ln X_{3}$ (Services GDP)

$Y\left(\right.$ total GDP/cap) $=\beta_{0}+\beta_{1} \ln X_{1}$ (Agricultural $\mathrm{GDP} /$ cap) $+\beta_{2} \ln X_{2}$ (Industrial GDP/cap) $+\beta_{3} \ln X_{3}$ (Services GDP/cap)

The ambition of the regression is to determine functional elasticity existing between the total GDP or total GDP per capita on one side, and agricultural, industrial and services sectors' GDP respectively GDP per capita on the other side. The logarithmic regression is conducted both for Sub-Saharan economy and also for the World economy as a whole. The idea is to compare the African and World economy and to highlight differences existing between Sub-Saharan Africa and the World. All calculations are conducted in STATISTICA 7.0.

\section{Analysis and discussion}

During the last two decades, global economy experienced a significant growth. The world GDP has increased from 22 trillion USD to more than 74 trillion USD during the period $1990-2013$. It means the world GDP has increased 3.4 times and its average annual growth rate reached cc $6 \%$ during the twenty year period. The GDP growth seems not to be as extreme when constant prices (USD, 2005) are applied, but it is still remarkable (from about 30 trillion to 55.9 trillion USD). From this perspective, the world GDP has increased 1.84 times which represents the annual growth rate at the level of $3 \%$. When performing the analysis of individual GDP components (both in current and constant USD prices, 2005;) the following characteristics will result (figures in brackets are related to constant prices): the world agricultural GDP grew 3.2 times (1.8 times) in the reference period, the world industrial GDP increased 2.45 times (1.32 times) and the world GDP in the service sector rose 4.07 times (2.24 times) during the surveyed period (see table 1 for more details). The share of particular sectors in the total world GDP has changed subsequently (agriculture from $5.14 \%$ to $4.36 \%$, industry from $37.50 \%$ to $27.03 \%$, and services from $57.35 \%$ to $68.60 \%$ ).

Taking into account the Sub-Saharan countries, their GDP has increased from about 300 billion USD to almost 1.6 trillion USD during the reference period; expressed in constant prices, it jumped from 412 billion USD to about 945 billion USD. In other words, the value of the GDP rose 5.36 times (or 2.29 times using constant prices). In terms of the average annual growth rate, the Sub-Saharan countries experienced a significant growth both in current and constant prices by $7 \%$ a year (resp. 3\%). The contribution of agriculture to the total GDP increased 2.01 times (0.85 times expressed in constant prices), industrial GDP rose 6.94 times (3.44 times) and GDP in the service sector went up 6.25 times (2.34 times).

Analysing the composition of the GDP in Sub-Saharan countries, the following changes can be observed: the share of agriculture in total GDP decreased significantly from $26.0 \%$ in 1990 to $9.78 \%$ in 2013 ; on the other hand, the share 
of industry increased from $30.1 \%$ to $45.24 \%$ during the same period and the share of the service sector in total regional GDP remained approximately on the same level $(43.9 \%$ in 1990 and $44.97 \%$ in 2013).

Comparing the Sub-Saharan economic development and the development of the world economy, much more dynamic growth in the Sub-Saharan economy can be observed. African economy has been growing much faster especially in the industrial and service sectors. Despite the dynamic growth in the agricultural sector, its share in the economy has been decreasing; on the other hand, the share of services and especially industry in total GDP is becoming more and more important. It is worth highlighting the much higher dynamics of the industrial added value in comparison with the service sector. While the service sector has been the leader of the world's economic growth during the recent two decades, it was the sector of industry in Africa. While almost $70 \%$ of GDP is represented by the service sector at the global level, it is about $45 \%$ in Sub-Saharan Africa. Sub-Saharan economies thus stand in contrast to the developed countries, where the share of services in total GDP ranges usually from 70 to $90 \%$ (Table 1).

Different GDP structure indicates that a typical economic structure based on the SIA model has not been reached in many Sub-Saharan countries (reference year 2011), mainly due to their transition processes. Sub-Saharan Africa is represented by all four basic types of economies based on their GDP structure. The most important type of the GDP formation is represented by the SIA model (18 from the total 37 surveyed countries, namely Seychelles, Eritrea, Gambia, Mauritius, Chad, South Africa, Namibia, Senegal, Madagascar, Lesotho, Kenya, Uganda, Cameroon, Sudan, Ghana, Mozambique, Zambia and Tanzania). The share of services in total GDP ranges in these countries from $42.9 \%$ (Zambia and Tanzania) to $84.2 \%$ (Seychelles) which is the highest proportion of all surveyed countries. High share is observed for Eritrea (70.5\%), the other economies do not reach the value of $70 \%$. Comparing to the year 1990, all countries (with an exception of Madagascar) have strengthened the proportion of services in their total GDP structure (Zambia by more than $18 \%$, Uganda by more than $16 \%$ ). Industry as the second most important GDP component reaches high values in Lesotho (41\%) or Zambia (nearly 38\%) and with an exception of five states (Seychelles, Eritrea, Gambia, Madagascar and Kenya) it does not fall below $30 \%$. Although these Sub-Saharan economies have reached the modern SIA model, their share of agriculture in total GDP formation remains high (over $20 \%$ in Tanzania, Zambia, Kenya, Sudan,

\begin{tabular}{|c|c|c|c|c|c|}
\hline & & & $\begin{array}{c}1990 \\
\text { bn USD }\end{array}$ & $\begin{array}{c}2013 \\
\text { bn USD }\end{array}$ & $\begin{array}{c}\text { Fix base index } \\
\text { (base, 1990) }\end{array}$ \\
\hline \multirow{8}{*}{ World } & \multirow{4}{*}{$\begin{array}{c}\text { constant } 2005 \\
\text { UDS }\end{array}$} & GDP total & 30291 & 55929 & 1.84 \\
\hline & & Agriculture & 1557 & 1836 & 1.18 \\
\hline & & Industry & 11363 & 15100 & 1.32 \\
\hline & & Services & 17371 & 38992 & 2.24 \\
\hline & \multirow{4}{*}{ current USD } & GDP total & 22001 & 74909 & 3.40 \\
\hline & & Agriculture & 1131 & 3269 & 2.89 \\
\hline & & Industry & 8253 & 20250 & 2.45 \\
\hline & & Services & 12617 & 51390 & 4.07 \\
\hline \multirow{8}{*}{$\begin{array}{l}\text { Sub-Saharan } \\
\text { Africa }\end{array}$} & \multirow{4}{*}{$\begin{array}{c}\text { constant } 2005 \\
\text { UDS }\end{array}$} & GDP total & 412 & 945 & 2.29 \\
\hline & & Agriculture & 107 & 92 & 0.85 \\
\hline & & Industry & 124 & 427 & 3.44 \\
\hline & & Services & 181 & 425 & 2.34 \\
\hline & \multirow{4}{*}{ current USD } & GDP total & 300 & 1.607 & 5.36 \\
\hline & & Agriculture & 78 & 157 & 2.01 \\
\hline & & Industry & 90 & 625 & 6.94 \\
\hline & & Services & 132 & 825 & 6.25 \\
\hline
\end{tabular}

Source: WDI database and own calculation, 2014

Table 1: The world and Sub-Saharan GDP value and structure $(1990-2013)$. 
Ghana, Uganda, Madagascar), just some counties reach the structure comparable to developed countries (Seychelles, South Africa). Comparing with the situation in 1990, all countries (with an exception of Zambia) experienced decline in the share of agriculture in GDP (nearly by $32 \%$ in Uganda) (Figure 1).

Seven Sub-Saharan economies (Togo, Benin, Rwanda, Malawi, Comoros, Burundi and Burkina Faso) are characterized by the SAI model. The most important sector of services reaches proportions in GDP in a range from 38.6\% (Burkina Faso) to $58.2 \%$ (Togo). Comparing to 1990 , the share declined in Burkina Faso, Comoros and Benin at the expense of growing industry (Figure 2).

The share of industrial sector in the GDP is relatively low ranging from $14.4 \%$ (Comoros) to $30.3 \%$ (Burkina Faso). Economies of these states have been developing differently over the last two decades. While industry strengthened its position in the GDP structure in some above mentioned countries, a decline experienced the other four states (Malawi by more than 12\% from 1990 to 2011). Agriculture plays an important role reaching nearly one-third share in the GDP formation (more than $40 \%$ in Comoros). In all countries (with an exception of Burkina Faso), the share has been shrunk over the surveyed period.

The ISA model has been found in the case of 8 economies (Botswana, Zimbabwe, Swaziland, Cote d'Ivoire, Mauritania, Guinea, Angola and Republic Congo). The countries are characterized by high share of industry in their GDP structure which ranges from $42.9 \%$ (Cote

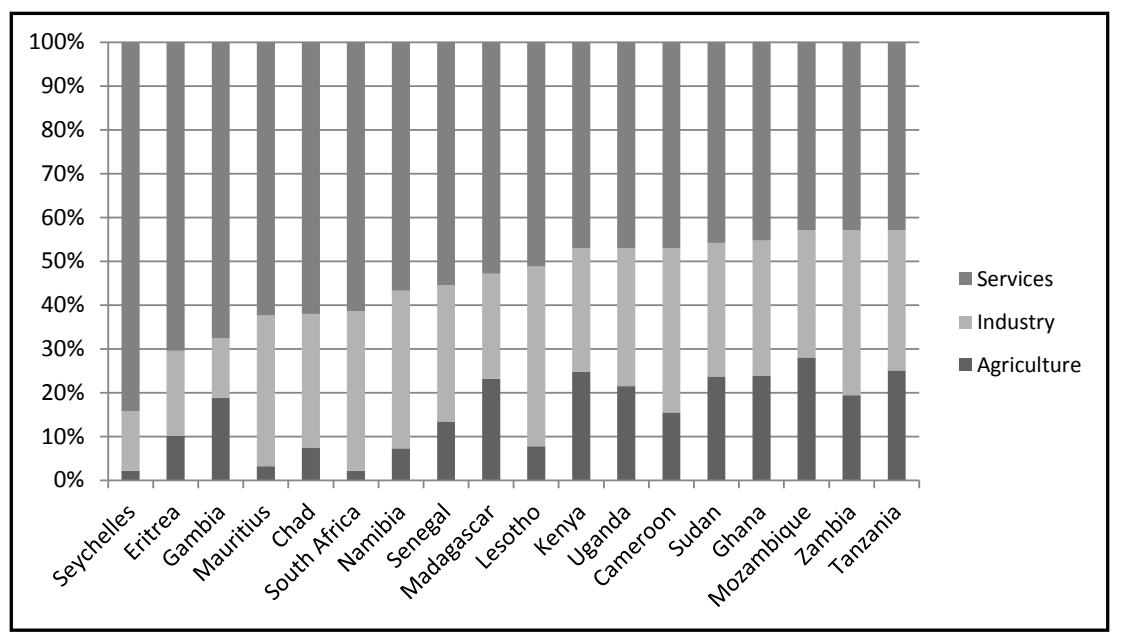

Source: WDI database and own processing, 2014

Figure 1: GDP structure in Sub-Saharan SIA countries (in 2011).

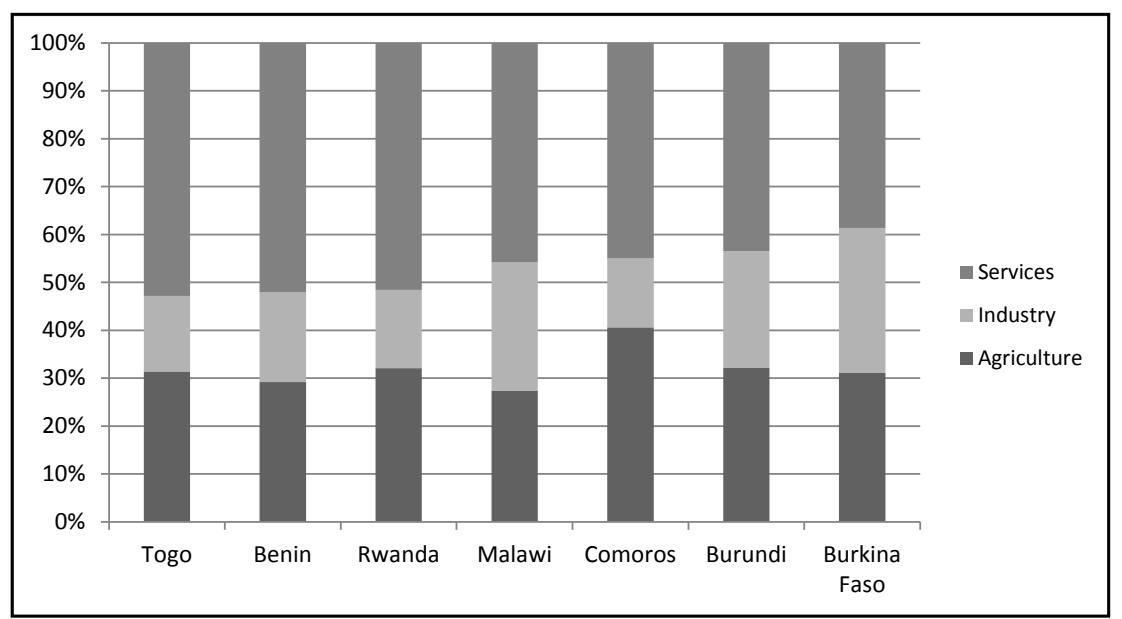

Source: WDI database and own processing, 2014

Figure 2: GDP structure in Sub-Saharan SAI countries (in 2011). 
d'Ivoire) to $76.6 \%$ (Republic Congo). All surveyed economies have increased their industrial GDP share over last two decades at the expense of services with an exception of Botswana where the position of services is continuously strengthening and moves closer to the SIA model. Agriculture as the smallest component of the GDP formation reaches shares from $2.6 \%$ in Botswana to nearly $25 \%$ in Cote d'Ivoire (Figure 3 ).

The last type, represented by ASI model, is a model of 4 surveyed Sub-Saharan economies (Ethiopia, Mali, Sierra Leone and Democratic Republic of the Congo). The share of agriculture in GDP ranges from $35.0 \%$ (Mali) to $54.6 \%$ (Sierra Leone). While Ethiopia and Mali have reduced their agricultural share in GDP in comparison with 1990, Sierra Leone and Democratic Republic of the Congo experienced an opposite trend (increase by $10.5 \%$, resp. $13.5 \%$ over the same period). Industrial development remains at a low level, expressed as a percentage of GDP formation, it ranges from less than $12 \%$ in Sierra Leone (decreasing trend) to slightly over $30 \%$ in Mali (increasing trend). The composition of Mali's GDP is nearly balanced and current trends may lead to a shift to the SAI model in the near future (Figure 4).

When analysing Sub-Saharan Africa as a whole, the SIA model will result; however comparing the region with the world economy two significantly different SIA models (with regard to their composition) will be found. While the share of agriculture in the world's GDP reaches about $4 \%$, it is about $12 \%$ in Sub-Sahara.

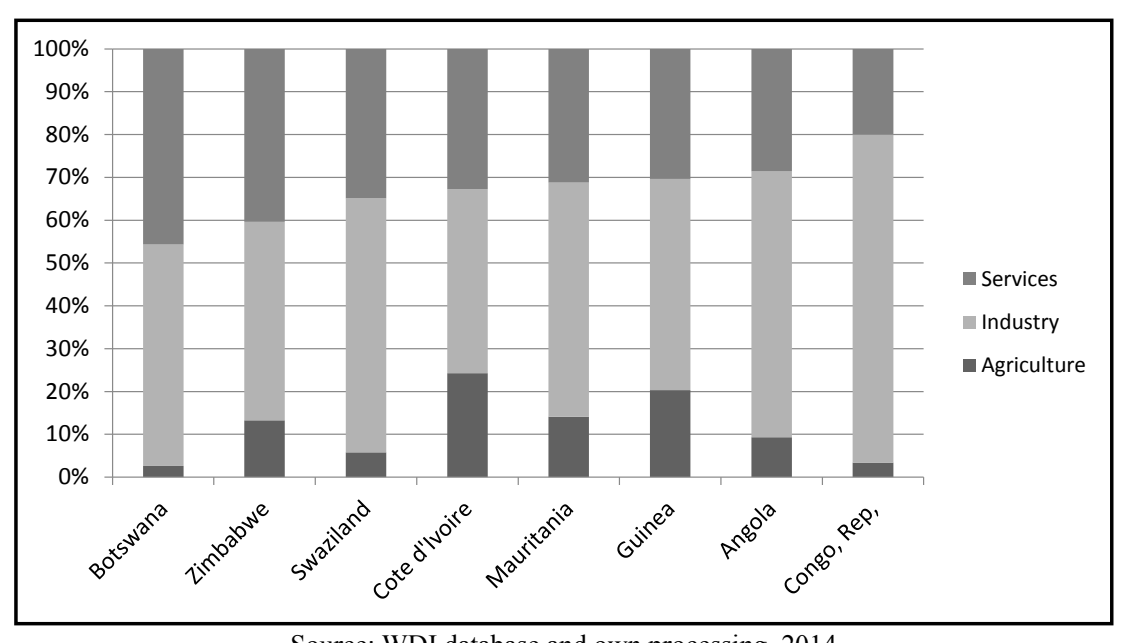

Source: WDI database and own processing, 2014

Figure 3: GDP structure in Sub-Saharan ISA countries (in 2011).

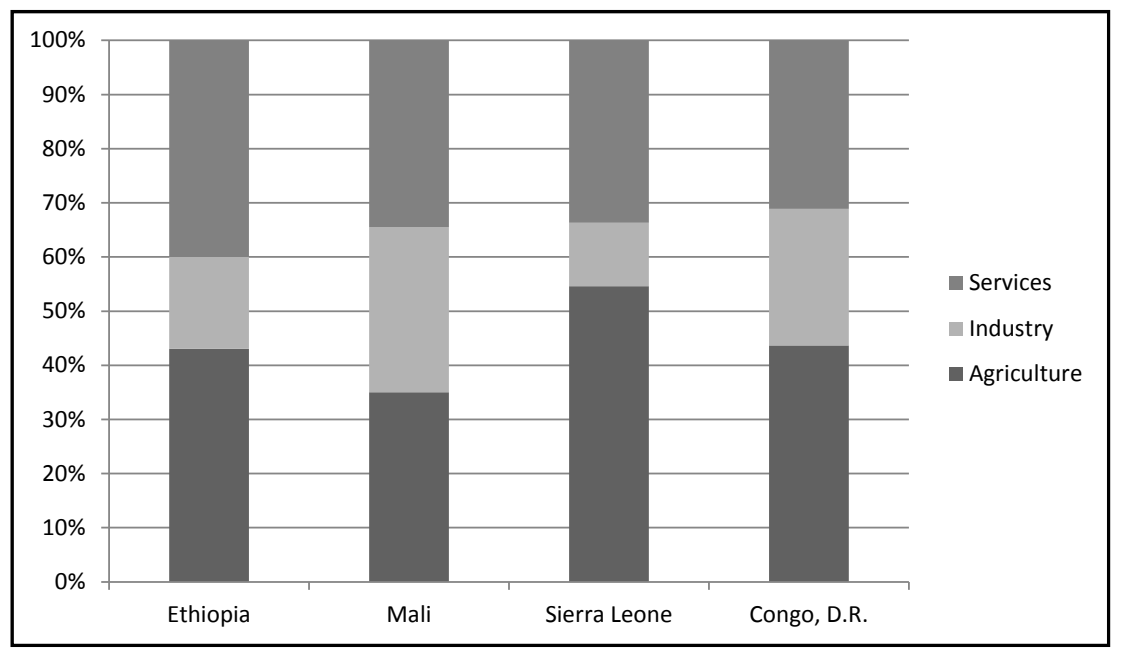

Source: WDI database and own processing, 2014

Figure 4: GDP structure in Sub-Saharan ISA countries (in 2011). 
Sub-Saharan Africa has higher proportion of industry in relation to the total GDP (43\%) than the world economy (38\%). The services sector is much less important in Sub-Sahara (45\%), compared with the world average (over 57\%).

To understand the economic development in Sub-Saharan Africa, it is necessary to take into consideration the fact that the region experienced significant changes not only with respect to its economic development as a whole, but especially with respect to the development of its economic structure during the recent two decades. All surveyed countries experienced much bigger changes in their GDP structure than those typical for the world economy. The share of the agricultural GDP in the total GDP shrunk only by $0.78 \%$ in the world, while by $16.2 \%$ in Africa. A disproportion can be found also when evaluating proportion of industry in the total GDP (the share of industry in the world GDP dropped by $10.48 \%$, but in Sub-Saharan Africa, it increased by $8.89 \%$ ). Less divergent development was experienced in services, where the share of services increased by $11.26 \%$ in the world economy and by $7.34 \%$ in surveyed African countries. The above mentioned results make it evident that the Sub-Saharan economy has been changing rapidly. Despite of the fact that the region and its countries have reached such structure, which is in general comparable to the world economic structure, the current state of African economy is still far from modern standards and the process of economic transformation has not been completed yet.

There are also very significant differences between African countries. The Republic of Congo, for example, experienced a major change in its GDP structure (the share of agriculture in total GDP has changed almost by $10 \%$; the shares of industry and services have changed by $36 \%$, resp. $27 \%$ ). On the other hand, Kenya reached only a limited change in its GDP structure. The regions and countries in Sub-Saharan Africa are going through different stages of their economic development. While some of them have already fully transformed their economies, many others have not yet completed their process of transformation. The fully transformed countries can be found in Northern Africa. Focusing on the Sub-Saharan part, the following countries may be considered as transformed: Seychelles, Eritrea, the Gambia, Mauritius, Chad, South Africa, Namibia, Senegal and Lesotho. The other countries are still going through different stages of transformation, despite of the fact that their economies have already reached the SIA or SAI structure. Many countries still have not reached an appropriate level of services in their total GDP and the share of the agricultural sector in the GDP remains enormously high (as evident from the Figure 4).

The differences are apparent not only in relation to annual growth (both to total and per capita GDP growth), but they also exist in the GDP sensitivity and correlation in relation to changes in their individual components (agriculture, industry and services).

The Tables 2 and 3 provide information about GDP formation in Sub-Saharan Africa and in the world. Substantial differences are evident if comparing Sub-Saharan Africa and the world in their GDP formation. Differences are apparent not only in relation to the annual growth (both total and per capita), but they also exist in the GDP sensitivity and correlation in relation to changes in its particular components (agriculture, industry and services).

High level of correlation is apparent in relation of total Sub-Saharan GDP and GDP generated by industry and services. On the other hand, very low correlation can be observed in mutual relation of total and agricultural GDP; expressed on per capita basis, it is even negative. The sensitivity of total Sub-Saharan GDP on changes in its particular components differs in comparison with the rest of the world. Differences are evident especially in relation to agriculture. African GDP is more sensitive to changes in agricultural sector. Contrary, the sensitivity of GDP to changes in industry is almost the same both in Sub-Sahara and the other world regions. There is only little dependence of African GDP on changes in the service sector compared to the world economy. It can be stated that primary and secondary sectors play much more important role in generating total GDP in Africa than it is typical in the rest of the world, especially in developed countries.

As mentioned above, Sub-Saharan Africa experienced much higher dynamics of the economic development in comparison with the world economy during the period observed. However, another picture appears when comparing trends in the GDP on a per capita basis. While the world GDP per capita has increased from 5,738 USD in 1990 to 7,538 USD in 2011 (by $31 \%$ ), the increment from 811 USD (1990) to 978 (2011) in Sub-Saharan Africa represented an increase only by $21 \%$. The reason for such 


\begin{tabular}{|c|c|c|c|c|c|c|c|c|c|c|}
\hline & \multicolumn{5}{|c|}{ World } & \multicolumn{5}{|c|}{ Sub-Saharan Africa } \\
\hline & 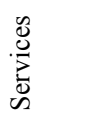 & 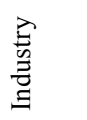 & 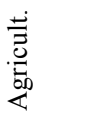 & 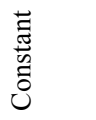 & نं & 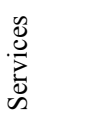 & 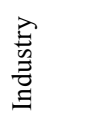 & 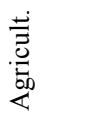 & 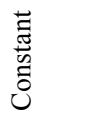 & نं \\
\hline Endogenous variables & 0.608 & 0.353 & 0.041 & 0.7824 & & 0.562 & 0.322 & 0.195 & 0.58 & \\
\hline $\begin{array}{l}\text { Stand. error for indiv. var. } \\
\text { incl. constant }\end{array}$ & 0.004 & 0.006 & 0.004 & 0.0198 & 0.3237 & 0.042 & 0.015 & 0.026 & 0.345 & -0.816 \\
\hline R2, Standard error for $y$ & 0.999 & 0.001 & $\# \mathrm{~N} / \mathrm{A}$ & $\# \mathrm{~N} / \mathrm{A}$ & 0.8962 & 0.994 & 0.008 & $\# \mathrm{~N} / \mathrm{A}$ & $\# \mathrm{~N} / \mathrm{A}$ & 0.974 \\
\hline F-stat, DOF & 68578 & 18 & \#N/A & $\# \mathrm{~N} / \mathrm{A}$ & 0.9612 & 918.09 & 18 & \#N/A & $\# \mathrm{~N} / \mathrm{A}$ & 0.896 \\
\hline
\end{tabular}

Source: own calculation - using data from WDI database, 2014

Table 2: Logarithm regression results (GDP per capita, USD, const. 2005).

\begin{tabular}{|c|c|c|c|c|c|c|c|c|c|c|}
\hline & \multicolumn{5}{|c|}{ World } & \multicolumn{5}{|c|}{ Sub-Saharan Africa } \\
\hline & $\sum_{0}^{0}$ & 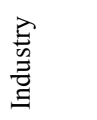 & 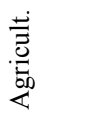 & $\begin{array}{l}\text { 芯 } \\
\text { Uี } \\
\tilde{0}\end{array}$ & 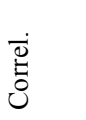 & 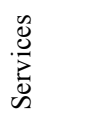 & $\begin{array}{l}\stackrel{\nexists}{E} \\
\stackrel{0}{\Xi} \\
\Xi\end{array}$ & 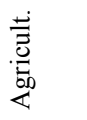 & 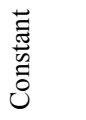 & $\begin{array}{l}\dot{0} \\
\stackrel{\Xi}{0}\end{array}$ \\
\hline Endogenous variables & 0.607 & 0.3532 & 0.0412 & 0.7619 & & 0.511 & 0.319 & 0.152 & 1.459 & \\
\hline $\begin{array}{l}\text { Stand. error for indiv. } \\
\text { var. incl. constant }\end{array}$ & 0.0036 & 0.0059 & 0.0039 & 0.0454 & 0.794 & 0.028 & 0.016 & 0.027 & 0.718 & 0.297 \\
\hline R2, Standard error for $y$ & 0.9999 & 0.001 & $\# \mathrm{~N} / \mathrm{A}$ & $\# \mathrm{~N} / \mathrm{A}$ & 0.966 & 0.999 & 0.008 & $\# \mathrm{~N} / \mathrm{A}$ & $\# \mathrm{~N} / \mathrm{A}$ & 0.993 \\
\hline F-stat, DOF & 233247 & 18 & $\# \mathrm{~N} / \mathrm{A}$ & $\# \mathrm{~N} / \mathrm{A}$ & 0.986 & 6753.7 & 18 & $\# \mathrm{~N} / \mathrm{A}$ & $\# \mathrm{~N} / \mathrm{A}$ & 0.989 \\
\hline
\end{tabular}

Source: own calculation - using data from WDI database, 2014

Table 3: Logarithm regression results (GDP, bn. USD, const. 2005).

development can be explained by very dynamic population growth in Africa. Information on GDP development on a per capita basis in the world and in Sub-Saharan Africa is provided in Table 4.

The results confirm the findings that the GDP development in Africa much more depends on agricultural and industrial sectors than it is common in the rest of the world. This can be also confirmed by the analysis of the GDP development at a per capita basis (for details see table 4). Further analysis performed at a per capita basis also proved a significant relationship between total GDP per capita and GDP per capita generated by agricultural sector. This result points to high dependency of the people living in the SubSaharan region on agricultural activities and on the performance of the agricultural sector Mwabu and Thorbecke, (2004).

Sub-Sahara is heavily dependent on agriculture, especially when taking into account the number of economically active population. When applying the Holub's methodology on the labour market structure in the countries surveyed, agriculture plays the most significant role in job creation in many countries. It is evident that most Sub-Saharan countries are still in the traditional stage of economic development (ASI model) in terms of labour market. Only several countries have reached the SIA (Angola, Namibia, Mauritius, South Africa and Algeria) or SAI (Gabon, Botswana, Sao Tome and Principe, Republic of the Congo and Senegal) structure. While the majority of the Sub-Saharan countries surveyed has already reached the SAI or SIA model (modern type of economy) in terms of economic structure, the traditional type of economy (ASI) dominates when labour market is taken into account (see Figure 5). Low number of workforce in industry and low level of industrial development on the one hand, and very high level of employment in agriculture on the other remain essential problems of the region Tiffen (2003); Kingdon et al. (2006). Underdeveloped infrastructure Ajakiye and Ncube (2010and low level of development in industrial and service sectors are factors dragging Sub-Saharan economy down. Population living in the region does not have any other choice but to remain in agriculture, however agriculture is characterized by low economic performance and also by limited added value per capita as well as by low level of wages Rezek et al. (2011); Henley (2012) (Figure 5). 


\begin{tabular}{|l|l|r|r|c|c|}
\hline & & 1990 & 2011 & \multirow{2}{*}{ Basic index } & \multirow{2}{*}{ Chain index } \\
\cline { 3 - 5 } & & USD & USD & & \\
\hline \multirow{4}{*}{ World } & GDP per capita & 5738 & 7538 & 1.31 & 1.013 \\
\cline { 2 - 6 } & Agriculture & 295 & 317 & 1.08 & 1.003 \\
\cline { 2 - 6 } & Industry & 2153 & 2916 & 1.35 & 1.015 \\
\cline { 2 - 6 } & Services & 3291 & 4305 & 1.31 & 1.013 \\
\hline \multirow{3}{*}{ Sub-Saharan Africa } & GDP per capita & 811 & 978 & 1.21 & 1.009 \\
\cline { 2 - 6 } & Agriculture & 211 & 115 & 0.55 & 0.972 \\
\cline { 2 - 6 } & Industry & 244 & 421 & 1.72 & 1.026 \\
\cline { 2 - 6 } & Services & 356 & 442 & 1.24 & 1.010 \\
\hline
\end{tabular}

Source: own calculation - using data from WDI database, 2014

Table 4: The world and Sub-Saharan GDP per capita and its structure (1990 - 2011, constant prices 2005).

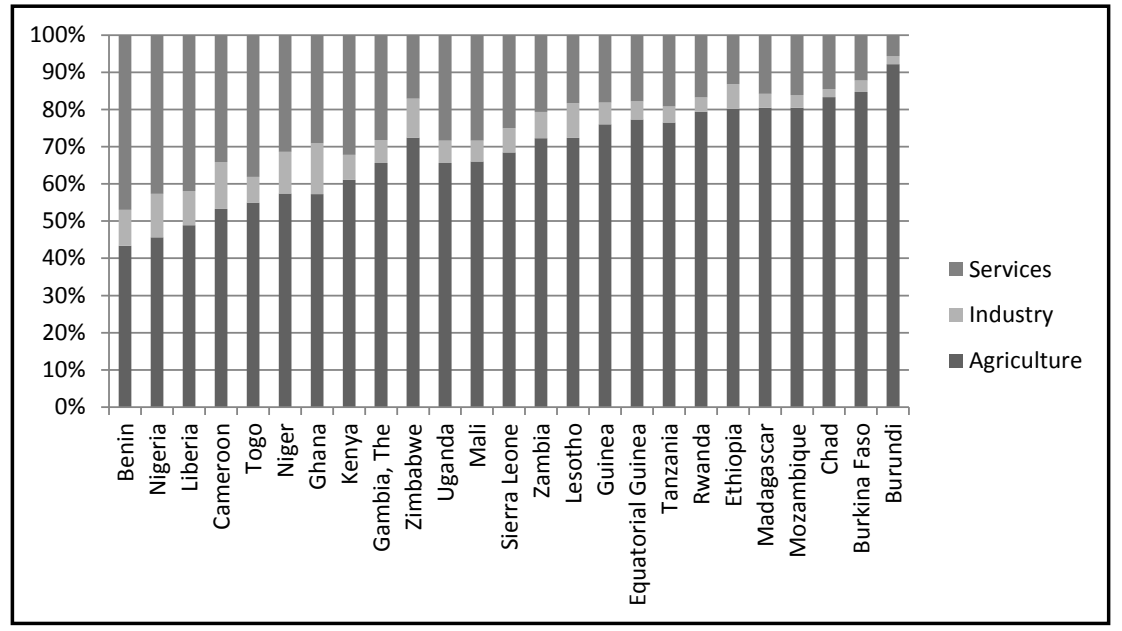

Source: WDI database and own processing, 2014

Figure 5: Sub-Saharan ASI countries according to labour employment (in 2011).

\section{Conclusion}

The analysis illustrates the specificity of Sub-Saharan Africa in the world economy. Its GDP and GDP per capita performance is very low, however the annual GDP growth rate is much higher in comparison to the world average. The problem of Sub-Saharan Africa remains in high level of population growth Jenicek (2010) which is not accompanied by a proportional growth of the economy Ezeh et al. (2012). This can explain why the annual growth of the GDP per capita in the Sub-Saharan region is far behind the annual growth of the Sub-Saharan economy as a total. Another remarkable fact is the quite specific structure of the Sub-Saharan economy. The whole region is characterized by high importance of agriculture and industry within the whole economy (much more than it is typical for the world economy). On the other hand, the service sector is still not fully developed. It is to be noticed that
Sub-Saharan Africa recorded significant changes in its GDP structure during the last two decades. In many countries, the share of agriculture in the GDP has been reduced significantly while the share of industry increased. The sector of services remains a weakness of the region. Its share in the total Sub-Saharan GDP is high; nevertheless, its growth is constrained. It is worth noting that agriculture remains an important source of job opportunities and especially an important income source for a significant share of population living in the region, despite the dominancy of services and industry in relation to total GDP.

Another important finding resulting from the analysis is the existence of significant differences within the Sub-Saharan countries in relation to the development of their total GDP value and GDP structure. Considering the economic structure of the countries surveyed, all four types of economies (SAI, SIA, ISA and ASI) can be found 
in Sub-Sahara. Taking into account the labour market, three types of economies SIA, SAI and ASI will result. It is evident that many economies are still in the process of development or transformation. When analysing differences which exist among the Sub-Saharan countries, they appear distinct in their GDP, especially in a per capita expression. Many countries of the surveyed sample reach their GDP per capita in the range from 1,000 to 12,000 USD a year (22 out of 43 countries), but there are also many countries (21 out of 43 ), where the GDP per capita reaches a value just from 245 to 900 USD a year. When analysing individual countries in greater detail, significant differences will appear in relation to annual economic growth and GDP per capita. There are countries (Uganda, Mozambique, Angola, Ethiopia, Burkina Faso, Chad, Ghana, Sudan, Botswana and Tanzania) where GDP exceeded a 5\% growth a year during the monitored period, but there are even countries with a negative GDP growth (Congo D.R. or Zimbabwe).

Sub-Saharan economy is very vulnerable and sensitive both in regional and world economic development. The region is still facing many political, economic and social problems such as instability, democratic deficit, low level of education, insufficient investments, local conflicts, etc. Collier and Vicente (2012); Bezemer and Jong-A-Pin (2013); Barbier (2010). SubSaharan Africa is also plagued by an intensive population growth, which is not accompanied by proportional economic growth. Some authors
Go et al. (2007); Thorbecke (2013) point out the disproportion in income distribution might become a problem for the stability and further development of the region in future. From the economic point of view it is worth noting that the transformation process in Sub-Saharan Africa still has not reached the level of the global economic transformation. A significant reduction of agriculture in total GDP is to be expected in the future, it is also possible to expect an increasing role of processing industry (food and raw materials processing as well as light industry) and services (financial, communication and transportation services) in regional GDP (both in relation to GDP and its structure and in relation to labour market). International trade could be another important factor to have a significant impact on Sub-Saharan economic development. A growth of inter-regional and especially intra-regional trade has a potential to stimulate development of African economy and its restructuring.

\section{Acknowledgements}

This paper was prepared with financial support of the projects „Socio-economic practices of sustainable development in the new industrialization". The project is founded by the Government of the Russian Federation, Grant 074-U01 and conducted within the ITMO University.

\section{Corresponding author:}

Doc. Ing. Karel Tomšik, Ph.D.

Department of Economics, Faculty of Economics and Management,

Czech University of Life Sciences Prague, Kamýcká 129, Praha 6-Suchdol, 16521, Czech Republic

Phone: +420 734123 432,E-mail: tomsik@pef.czu.cz

Doc. Ing. Luboš Smutka, Ph.D.

Department of Economics, Faculty of Economics and Management,

Czech University of Life Sciences Prague, Kamýcká 129, Praha 6-Suchdol, 16521, Czech Republic

E-mail:smutka@pef.czu.cz

\section{References}

[1] Ahmed, A. D., Suardi, S. Sources of economic growth and technology transfer in sub-Saharan Africa. South African Journal of Economics. 2007, Vol. 75, No. 2, p. 59-178. Online ISSN 1813-6982.

[2] Ajakaiye, O., Ncube, M. Infrastructure and Economic Development in Africa: An Overview. Journal of African Economies. 2010, Vol. 19, Supplement 1, p. 103-112. Online ISSN 1464-3723. 
[3] Anderson, K., Martin, W., Van Der Mensbrugghe, D. Would multilateral trade reform benefit Sub-Saharan Africans? Journal of African Economies. 2006, Vol. 15, No. 4, p. 626-670. Online ISSN 1464-3723.

[4] Barbier, E. B. Corruption and the Political Economy of Resource-Based Development: A Comparison of Asia and Sub-Saharan Africa. Environmental \& Ressource Economics. 2010, Vol. 46, No 4, p. 511-537. ISSN 0924-6460.

[5] Bezemer, D., Jong-A-Pin, R. Democracy, globalization and ethnic violence. Journal of Comparative Economics. 2013, Vol. 41 No. 1, Special Issue: SI, p. 108-125. ISSN: 0147-5967.

[6] Bussmann, M., Schneider, G., Wiesehomeier, N. Foreign economic liberalization and peace: The case of sub-Saharan Africa. European Journal of International Relations. 2005, Vol. 11, No. 4, p. 551-579. ISSN 1354-0661.

[7] Collier, P., Vicente P. C. Violence, bribery, and fraud: the political economy of elections in Sub-Saharan Africa. Public Choice. 2012, Vol. 153, No. 1-2, p. 117-147. ISSN 0048-5829.

[8] Ezeh, A. C., Bongaarts, J., Mberu, B. Global population trends and policy options. LANCET. 2012, Vol. 380, No. 9837, p. 142-148. ISSN 1474-547X.

[9] Go, Delfin et al. (2007) Poverty and inequality in Sub-Saharan Africa: Literature survey and empirical assessment. Annals of Economics and Finance. 2007, Vol. 8, No. 2, p. 251-300. ISSN 1529-7373.

[10] Henley, D. (2012). The Agrarian Roots of Industrial Growth: Rural Development in South-East Asia and sub-Saharan Africa. Development Policy Review. 2007, Vol. 30, Special Issue: SI, Supplement: 1, p. 25-47. ISSN 1467-7679.

[11] Hindls, R. et al. Statistika pro ekonomy. Professional publishing. 2007. ISBN 978-80-86946-43-5.

[12] Holub, A. A Brief Review of Structural Development in Developing ECAFE Countries. Economic Bulletin for Asia and the Far East. 1970, Vol. 11, No. 1-2, p. 4- 9. ISSN 0041-6371.

[13] Jenicek, V. Population problem in the future - challenges, questions. Agricultural Economics - Zemědělská Ekonomika. 2010, Vol. 56, No. 3, p. 97-107. ISSN 1805-9295.

[14] Jenicek, V. World population - development, transition. Agricultural Economics - Zemědělská Ekonomika. 2010, Vol. 56, No. 1, p. 1-15. ISSN 1805-9295.

[15] Johnson, R. Agriculture and trade in Sub-Saharan Africa - A review. Outlook on Agriculture. 2005, Vol. 34, No. 2, 71-76. ISSN 0030-7270.

[16] Kingdon, G., Sandefur, J., Teal, F. Labour market flexibility, wages and incomes in sub-Saharan Africa in the 1990s. African Development Review-Revue Africaine de Developpement. 2006, Vol. 18, No. 3, p. 392-427. Online ISSN 1467-8268.

[17] Kirkpatrick, C., Watanabe, M. Regional trade in sub-Saharan Africa: An analysis of East African trade cooperation, 1970-2001. Manchester School. 2005, Vol. 73, No. 2, 141-164. Online ISSN 1467-9957.

[18] Maitah, M., Saleem, N., Malec, K., Boubaker, M., Gouda, S. Economic value added and stock market development in Egypt. Asian Social Science. 2014, Vol. 11, No. 3, p. 126-134. ISSN 1911-2017.

[19] Mwabu, G., Thorbecke, E. (2004). Rural development, growth and poverty in Africa. Journal of African Economies. 2004, Vol. 13, No. 1, p. 16-65. Online ISSN 1464-3723.

[20] Ndulu, B. J. Infrastructure, regional integration and growth in Sub-Saharan Africa: Dealing with the disadvantages of geography and sovereign fragmentation. Journal of African Economies. 2006, Vol. 15, No. 2, p. 212-244. Online ISSN 1464-3723. 
[21] Rezek, J. P. et al. (2011). Assessing Total Factor Productivity Growth in Sub-Saharan African Agriculture. Journal of Agricultural Economics. 2011, Vol. 62. No. 2, p. 357-374. Online ISSN: $1477-9552$.

[22] Tekle, K. et al. (2008). Impacts of free trade area (FTA) within Eastern and Southern Africa countries and unilateral tariff elimination by other regions. Journal of Food, Agriculture \& Environment. 2008, Vol. 6, No. 2, p. 426-431. ISSN 1459-0255.

[23] Thies, C. G. The political economy of state building in sub-Saharan Africa. Journal of Politics, 2007, Vol. 69, No.3, p. 716-731. ISSN: 0022-3816.

[24] THORBECKE, E. (2013). The Interrelationship Linking Growth, Inequality and Poverty in Sub-Saharan Africa. Journal of African Economies. 2013, Vol. 22, No. 1, p. 15-48. Online ISSN 1477-9552.

[25] Tiffen, M. (2003). Transition in sub-Saharan Africa: Agriculture, urbanization and income growth. World Development. 2003, Vol. 31, No. 8, p. 1343-1366. ISSN: 0305-750X. 